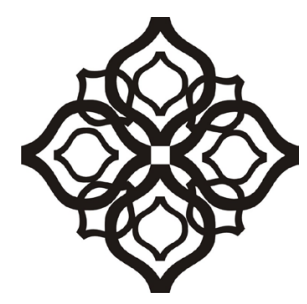

Shirkah

Journal of Economics and Business 


\section{Shirkah}

Journal of Economics and Business

Vol. 3, No. 2, May-August 2018

ISSN: 2503-4235 (p); 2503-4243 (e)

\section{Editor in Chief}

Dwi Condro Triono

\section{Managing Editor}

Jasanta Peranginangin

\section{Editorial Boards}

Abdul Azim Islahi,

Islamic Economics Institute, King Abdulaziz University, Saudi Arabia

Abu Umar Faruq Ahmad,

UBD School of Business and Economics Universiti, Brunei Darussalam

Cedomir Nestorovic,

ESSEC Business School Asia Pacific, Singapore

Fitri Wulandari,

Faculty of Islamic Economics and Business, IAIN Surakarta, Indonesia

Johan Fischer,

Department of Social Sciences and Business Roskilde Universitetscenter, Denmark Muhamed Zulkhibri,

Islamic Research and Training Institute, Islamic Development Bank, Saudi Arabia M. Kabir Hassan,

Department of Economics and Finance, University of New Orleans, United States Musa Asy'arie,

Faculty of Islamic Economics and Business, IAIN Surakarta, Indonesia Nunung Nurul Hidayah,

Aston Business School, Aston University, Birmingham, United Kingdom

Saim Kayadibi,

Department of Economics, Kulliyyah of Economics and Management Science, International Islamic University Malaysia, Malaysia 
Shaikh M Ghazanfar,

Departement of Economics, University of Idaho, Russian Federation

Sigit S. Wibowo,

Department of Management, Faculty of Economics and Business, Universitas Indonesia, Indonesia

Vihang R. Errunza,

Desmarais Global Finance Research Centre, Desautels Faculty and Management, McGill University, Canada

\section{Assistant to Editor}

M. Endy Saputro

M. Zainal Anwar

Shirkah Journal of Economics and Business is a peer-reviewed journal published three times a year (January-April, May-August and September-December) by Faculty of Islamic Economics and Business, Institut Agama Islam Negeri (IAIN) Surakarta Central Java, Indonesia. The main objective of Shirkah is to offer an academic space of exchange ideas and initiate the increase number of qualified article produced by postgraduate students, practitioners and academicians.

\section{Editorial Office}

Ruang Jurnal Shirkah

Lantai Dasar, Sayap Barat, Fakultas Ekonomi dan Bisnis Islam, IAIN Surakarta

Jln. Pandawa No. 1, Kartasura, Sukoharjo, Jawa Tengah Kode Pos. 57168

Phone (+62271) 781516 Fax: (+62271)782336

E-mail: shirkahjournal@iainsurakarta.ac.id; shirkahiainsurakarta@gmail.com Website: http://shirkah.or.id/ 


\section{Shirkah}

\section{Journal of Economics and Business}

Vol. 3, No. 2, May-August 2018

ISSN: 2503-4235 (p); 2503-4243 (e)

\section{Table of Contents}

\section{Articles}

Eko Fajar Cabyono

Lina Nugraha Rani

Macroprudential Policy on Sharia Banking Financing

The Indonesian Experience

Yulianti

Seeing a Buddhist Doing Business in Contemporary Indonesia An Interview with Mr. Sudhamek A.W.S

Fransisca Dwijayanti

Making Economics of Piety

Fashion, Lifestyle and Identity in Pop-Islamism Turn

Indah Piliyanti

Fintech Achieving Sustainable Development

The Side Perspective of Crowdfunding Platform

Taufik Nugroho

Aam S. Rusydiana

Macroeconomic Variables on Indonesian Sharia Capital Market

Hurdle Rate and Adverse Selection on Escalation of Commitment 


\title{
Fintech Achieving Sustainable Development The Side Perspective of Crowdfunding Platform
}

\author{
Indah Piliyanti \\ Faculty of Islamic Economics and Business, IAIN Surakarta \\ indah.piliyanti@gmail.com
}

\begin{abstract}
Crowdfunding has gradually been an emerging financing model of raising small amounts of money from a large number of people, mostly by means of optimizing certain website. The article proposes to explore the development of crowdfunding platform and the prospective of Islamic crowdfunding as the financial solution. The data has been gathered from certain website, under five standards: social network, event, user motivation, incentive versioning, and critical mass. The article reveals that along with other types of crowdfunding platforms, Islamic crowdfunding have disrupted sharia financing in Indonesia, yet the relate rule of financing have not accommodated this great development.
\end{abstract}

Keywords: crowdfunding, Islamic crowdfunding, micro financing.

\section{Introduction}

Ministry of Cooperative, Small and Medium Enterprise claims that the development of micro, small and medium enterprises (MSMEs) have steady improved year to year. In 2013, for an example, the number of MSMEs reachesat 57,895,721 units or increased by 2, 41\% from 2012 (Departemen Koperasi, 2015). This development would be a positive signal for Indonesia due to the MSMEs come to be necessary to advance the country's economics, at least taking effect on the huge contribution to the growth of Indonesian Gross Domestics Product. Consequently, 
the upsurge of MSMEs in Indonesia invites the proliferation of capital requirements. Needless to say that one of the obstacles of MSMEs and start-up business is, of course, capital (Lawton \& Marom, 2010).

Such financial institutions as banks and cooperatives have significantly been a main space for the businessman to obtain funding under certain terms and conditions (Alexakis \& Pappas, 2018; Alqahtani \& Mayes, 2018; Gray \& Zhang, 2017). However, not all businesses meet their criteria to be financed (Budisantoso $\&$ Nuritomo, 2016). In addition, it is available in Indonesia a funding concept called venture capital. This type of capital scheme denotes a financing concept that is carried out to a business with two dimensions, namely the business and social dimensions (Budisantoso \& Nuritomo, 2016). Recently,it has emerged a technologybased financing concept known as crowdfunding. This schemerepresents a revolution of venture capital models, yet going on a technological basis with a massive number of users (Agrawal, Catalini, \& Goldfarb, 2011; Chepurenko, 2015; Kanani \& Goodarzi, 2016). Crowdfunding has been a new alternative in the world of capital, offering a fast and easy financial process (Benna \& Benna, 2018; Chaney, 2018; Chirisa \& Mukarwi, 2018; Petruzzelli et al , 2018).

Crowdfunding has been situated as an alternative investment for business beginners. Those who starts a business, yet no have supporting financialcapital, crowdfunding may be alternative pathway (Blowfield, 2012; Boldea \& Sirghi, 2011; Harris, Edmunds, \& Chen, 2011; Testa, Nielsen, Bogers, $\&$ Cincotti, 2018). The $6^{\text {th }}$ world ranks of Indonesian internet users in 2014, according to $e$-Marketer Market Research Institute, and would be reach at 102.8 million users for the two years, could be the strength to realizing sustainable economic development. This article aims to identify the types of crowdfunding platforms that have already and continously established in Indonesia based on their focus and operational 
scope. This article also detects the uniqueness of the crowdfunding compared to that of US platforms and the potential Islamic crowdfunding platform in order to achieve sustainable development goals.

\section{Defining Crowdfunding}

The word "crowdfunding" consists of crowd and funding; the former refers to solid, while the latter means financing. Etymologically, this word has been interpreted as financing carried out by many parties, which are connected to each other, through a media, usually the internet (Mollick, 2014). In line with this understanding, crowdfunding has been defined as an effort to collect business capital with a relatively small number of many investors, where interested parties are connected to each other through the internet (Danmayr, 2014; Sulaiman, 2018). Crowdfunding has been also defined as an online capital demand activity by a project owner. Another definition denoteit as financing business/ projects that are formed on small capital of many investors, which are collected through a portal on the internet (Pereira, et.al, 2015). From the definitions, crowdfunding may be defined as capital-intensive financing collected through the internet. Capital intensive here refers to the collect capital that has been derived from small capital of several investors.

The crowdfunding platform has many types that represent different goals and platform categories. First, donation-based crowdfundingis the simplest type of crowdfunding. Crowdfunding usually consists of many investors whose purpose for donations, without expecting rewards from the project owner. This crowdfunding platform is usually reserved for those who are surged for a lot of money.It can be in the form of raising funds for social power that requires a lot of money. Second, sponsoring crowdfunding is a type of crowdfunding that aims to sponsor a project, such as making albums, films, comics or others. This type of crowdfunding 
entails of investors who have the same hobby tendencies. This type of crowdfunding provides less significant rewards, such as album CDs and concert tickets.

Third, pre-selling crowdfunding is the type which is almost the same as the type of sponsoring crowdfunding, instead only the donorcan support by means of buying products from a project. In doing so, the project can be continued to finish. This type locatesthe donor as the first buyer whom use the product, while the platform owners have a responsibility to ensure that every investor gets a product in the form of a purchased product. Fourth, loan-based crowdfundinghas a relationship between creditors and funders with the project owner. Investors in this crowdfunding are positioned as creditors, while the project owner is obliged to return the capital provided. This crowdfunding platform is usually the start-up business founders who are just starting businesses and need additional capital, as well as people who need funds for urgent needs (Gerber, Hui, \& Kuo, 2012). Funders in this crowdfunding get a bonus from the money they lend, and usually in the form of interest. The owner of the platform is tasked with analyzing the prospective borrower and then provides an assessment of the loan feasibility. Therefore, managing this type of crowdfunding is more complicated compared to previous crowdfunding types.

Fifth, equity-based crowdfunding platforms are a crowdfunding model that position funders as investors, as well as stock investments in the capital market. The funders have the right to funded projects. In addition, the funders have the right to monitor and direct the projects andthe investors in the capital market. Equity-based crowdfunding is the most complicated type of crowdfunding, due to platform owners work similar to capital markets. They manage the flow of capital and service rewards, including overseeing the performance of funded projects, so that the funders are comfortable in investing their capital in a project. 
This crowdfunding model has received serious attention by the United States government by issuing regulations to fund investment through crowdfunding platforms. The last one, Islamic crowdfunding or sharia crowdfunding is a crowdfunding platform model that operates according to Islamic principles in business. This model is fairly new in the midst of the development of the financial technology business, due to special market niches with the criteria for halal business.

\section{Crowdfunding for MSMEs}

Crowdfunding is a concept that has just been practiced in the world of funding for a business. Starting from such portal in America as Sellaband (2006), Indigogo (2008), Pledegemusic (2009) and Kickstarter (2009). At the beginning of its development, crowdfunding was widely used by art workers to get financial support for the proposed projects. The crowdfunding platform moves from reward-based to loan-based. The loanbased crowdfunding has been a crowdfunding platform that offers a loan service for a certain level of money. The development of this loan-based crowdfunding platform began around 2006 in America, then expanded to UK a year later (Freedman \& Nutting, 2014).

In 2010, a crowdfunding platform named GoFoundMe emerged, representing the new era of a donation-based crowdfunding. This platform has beena type of crowdfunding that does not reward funders because the collect money would be a charitable contribution (Freedman \& Nutting, 2014). The most up-to-date crowdfunding platform refers to equity-based crowdfunding platform starts in 2011 (Freedman \& Nutting, 2014). Capital-based crowdfunding has a very complex of money flows; it is necessary to protect those who invest capital. US government has solved the problem by issuing a regulation regarding capital-based crowdfunding. The government regulation provides protection for investors, it also limits the movement of crowdfunding platforms to get funds from such investors. 
In Indonesia, the first crowdfunding portal appear in 2012 is wujudkan.com. A year later followed by donation-based crowdfunding platform kitabisa.com was founded by Universitas Indonesia students. Recently, at least there are nine crowdfunding platforms in Indonesia. Of the nine platforms there are only five active platforms. From the five active crowdfunding platforms, there are only three crowdfunding platforms that provide capital to MSMEs (Micro, Small and Medium Enterprises), namely gandengtangan.com, modalku and indves.

\section{Gandengtangan}

Figure 1. GandengTangan Site

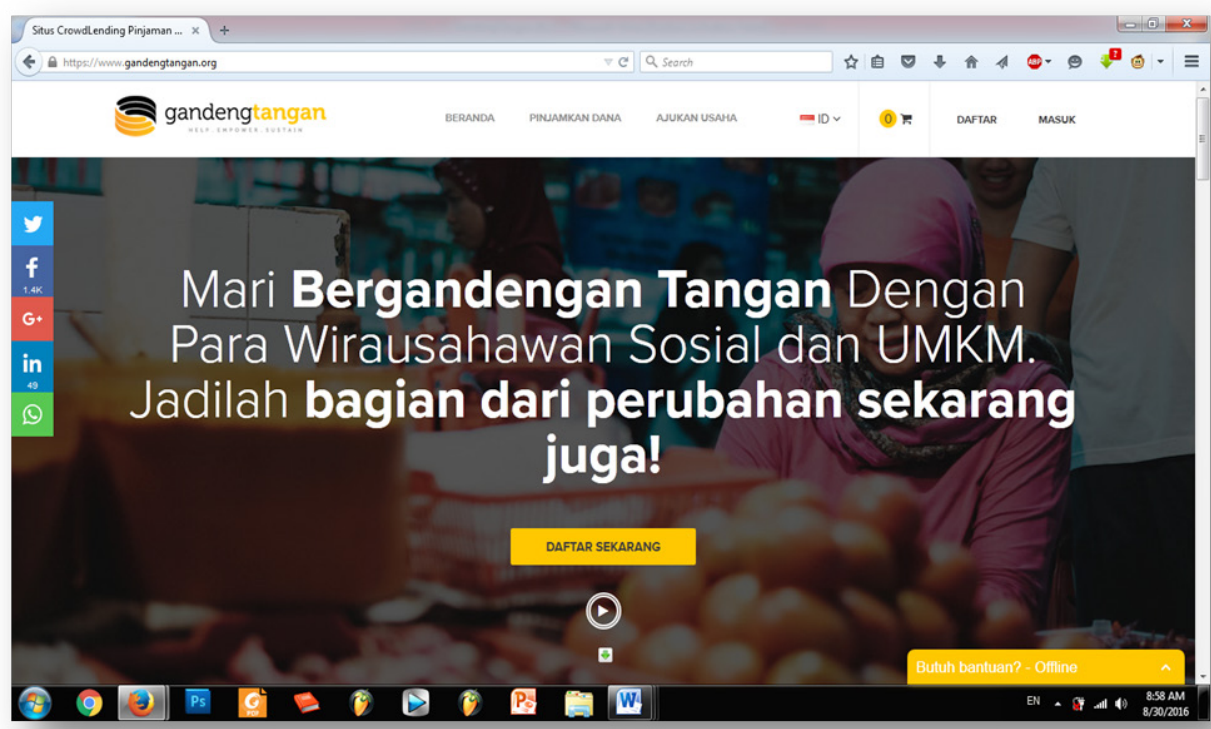

GandengTangan is a new crowdfunding portal in Indonesia. GandengTangan was established on March 15, 2015. Until now, GandengTangan has channeled funds in excess of Rp300,000,000.00 to MSMEs and start-up businesses. The number of businesses applying 
to this platform has reached 67 projects, with details of 16 businesses funded, 44 businesses in the campaign period, and 7 businesses not funded.GandengTangan is a loan-based crowdfunding where investors can invest a minimum of Rp50,000.00 and a maximum of Rp50,000,000. Investors will get a bonus (incentive) as promised. The bonuses are various, depending on the project owner which give the bonuses whether in the form of products or that of money.

GandengTangan is a non-profit company. For financial operations, every funded project is required to make a donation. This platform does not give a nominal amount of donations because of its voluntary type. GandengTangan method of fundingis also the same as the crowdfunding platform in general. In the beginning, the business owner sent a proposal through GandengTangan. After being approved, then the business owner promoted his business on social networks. The campaign period is quite long between 3 and 12 months. Investors who are interested in the business will invest in the business owner. While during the campaign period it has not been funded, the business owner can extend the campaign period to the next 90 days. After being funded 100\%, new business owners can withdraw their funds. As for the return process, GandengTangan provides a period of 24 months ( 2 years) for business owners to return capital. If the business owner has difficulty in repaying the loan, the term will be extended (restructuring). If until the restructuring period it has not been fulfilled, GandengTangan liquidate the business and its assets being used to repay the loan. 


\section{Modalku}

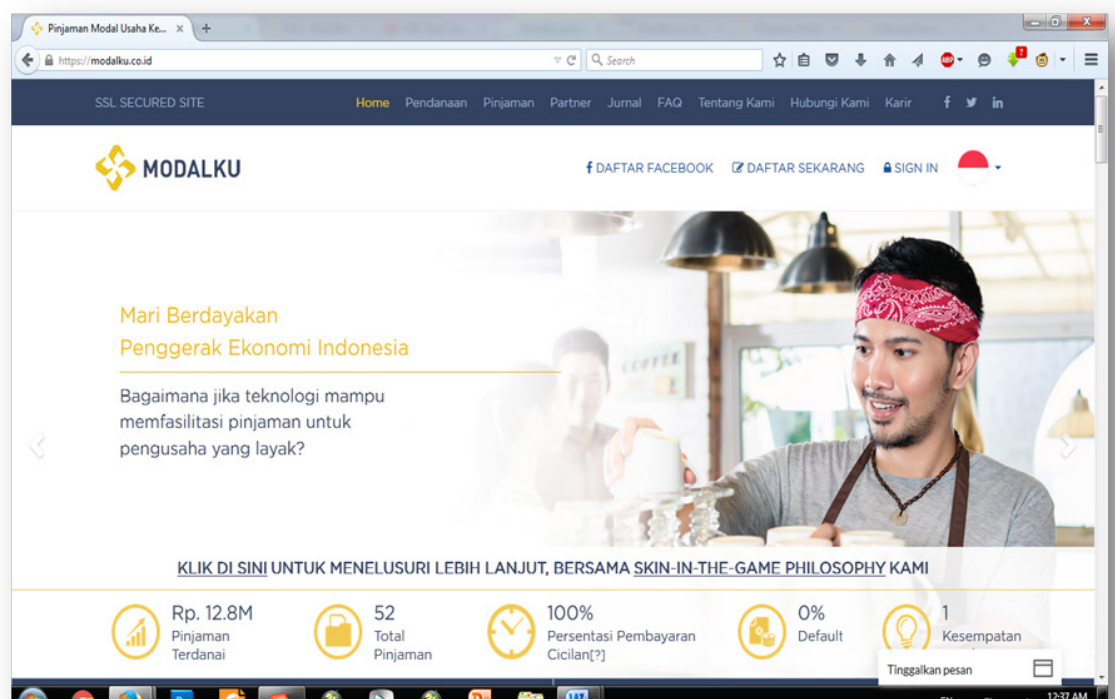

(2) 9 Pि

Figure 2. Modalku Site

Modalku would be a crowdfunding platform based on lending, similar to peer-to-peer lending. Unline GandengTangan which does not require interest, Modalku requires interest of around 14\% -20\% of the total loan. Meanwhile, the investors will receive a rate of return of $12 \%$ $18 \%$ of the total capital invested. Modalku was established on February 21, 2012. For the next four year, Modalku has got supporting for the fund of Rp12,800,000,000.00 to 52 businesses. With such a large loan, Modalku is the largest crowdfunding platform in Indonesia. Furthermore, the funding process of Modalku is quite different from other crowdfunding platforms. In general, to get funding from crowdfunding, business owners must campaign for their projects. In Modalku, the business owners do not need to conduct business campaign, only sending a loan request to 
Modalku. When the application is received, the funds can be disbursed for 3-4 working days.

Modalku also receives investment at any time, it does not depend on the campaign period. An investor who joins a Modalku member, he has the right to invest at any time. The invested funds will be collected and stored. If there is a select business, the funds are disbursed according to the request of the business owner. This investment process is the same as that of bank, yet Modalku is more internet-based.

\section{Indves}

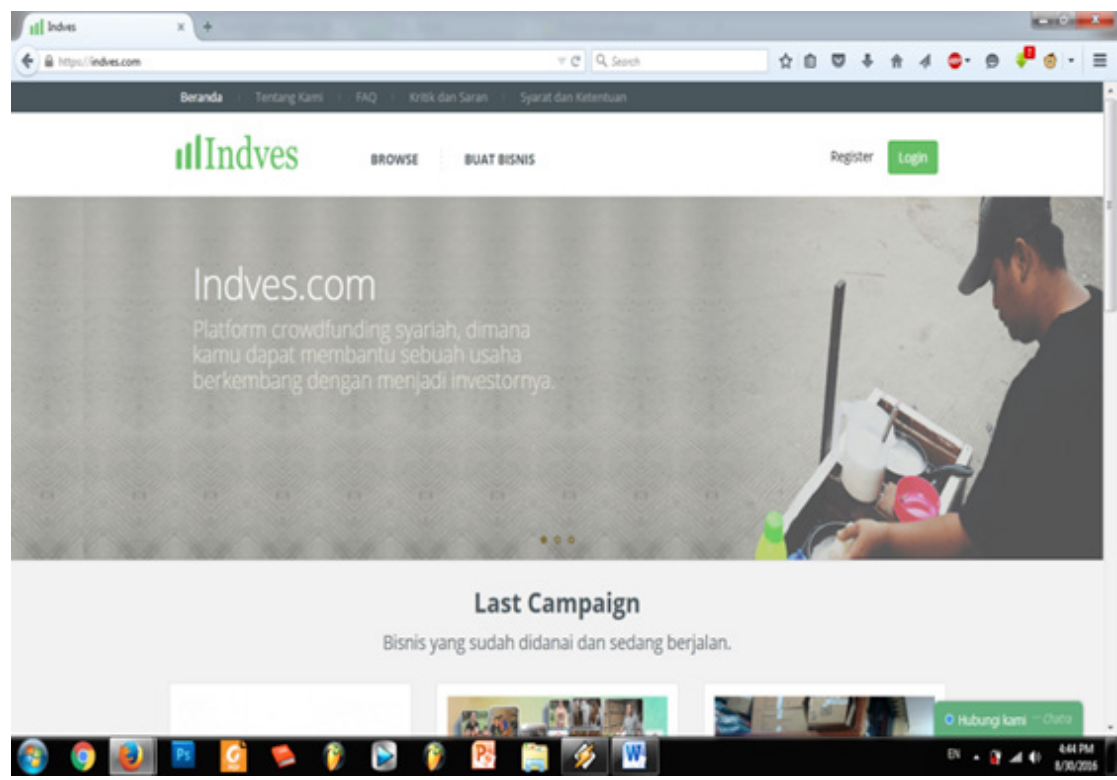

Figure 3. Indves Site

Indves would be the first sharia-based crowdfunding in Indonesia, arguing that the incentive system has been issued in the form of profit sharing. The business which is being profitable investors will receive incentives; conversely, while getting loss it means the investors would not 
get incentives. This site was established on January 4, 2016. Until now, the distributed funds have reached at Rp160,852,000.00. The funds have been channeled to six MSMEs businesses in the Jakarta and surrounding areas. For one year, Indves has been able to attract the attention of investors. It is sharia-based that feasibly invites some to get the Islamic incentive system. Indves has a method similar to another crowdfunding, starting with funding applications, applying the campaign period, then funds can be disbursed. Even though the project is not $100 \%$ funded, the business owners are allowed to collect the funds while the campaign period has ended. This system proposes to financing for MSMEs.

\section{Scrutinizing the Crowdfunding Complexities}

Considering the proposed categorization (Hemer, 2011), GandengTangan platform is loan-based crowdfunding with a peer to peer lending system. This system offers a loans from person to person. The platform has been designed as a provider of campaign services. The rewards are also personal, consisting of parties who have projects and those who fund the project. GandengTangan has the easiest level of management complexity among the three platforms. Although Modalku platform is also a loan-based crowdfunding platform, instead difficult to say belongs to a peer-to-peer loan. Project owners of Modalku can apply for loans and getting fund from collected from investors. Service rewards are the responsible platform manager. Seeing from the managerial system, this platform has a more complex level compared to GandengTangan. 
Table 1. Categorization of the Crowdfunding Platform

\begin{tabular}{|l|l|l|}
\hline Platform & \multicolumn{1}{|c|}{ Platform Type } & \multicolumn{1}{c|}{ Complexity } \\
\hline GandengTangan & Loan-base & +++ \\
\hline Modalku & Loan-base & ++++ \\
\hline Indves & Equity-base & ++++ \\
\hline
\end{tabular}

Source: data processed, 2016

The Indves platform is an equity based crowdfunding implying that the management system is the most complicated one compared to the other two platforms. As a capital-based crowdfunding, Indves has a responsibility to monitor the performance of funded projects. If it is in a loss condition, the project owner is not obliged to pay service fees. With such complex responsibilities, this platform requiressome project analysts who will assess the project feasibility.

Each portal of the crowfunding has a different models. From the nine chosen variables, there are only five variables whose data is available on its websites. As a result of analysis, the pattern of crowdfunding in Indonesia are being explained on the table 2 .

Table 2. Crowdfunding Portal Working Pattern

\begin{tabular}{|l|l|l|l|l|l|}
\hline \multirow{2}{*}{ Portal } & \multicolumn{5}{|c|}{ Variable } \\
\cline { 2 - 6 } & SCN & \multicolumn{1}{|c|}{ Event } & $\begin{array}{c}\text { User } \\
\text { Motivation }\end{array}$ & $\begin{array}{c}\text { Incentive } \\
\text { Versioning }\end{array}$ & Critical Mass \\
\hline $\begin{array}{l}\text { Gandeng } \\
\text { Tangan }\end{array}$ & $\begin{array}{l}\text { Yes } \\
\text { (Facebook, }\end{array}$ & $\begin{array}{l}\text { Yes } \\
(3,6,12 \\
\text { Youtube, } \\
\text { Linkedin) }\end{array}$ & $\begin{array}{l}\text { UMKM } \\
\text { Funding and } \\
\text { early-stage } \\
\text { business }\end{array}$ & $\begin{array}{l}\text { Yes } \\
\text { (incentives } \\
\text { givenaccording to } \\
\text { the promise of the } \\
\text { project owner }\end{array}$ & $\begin{array}{l}\text { (newspaper } \\
\text { Sindo, Daily } \\
\text { Social, and } \\
\text { others) }\end{array}$ \\
\hline
\end{tabular}




\begin{tabular}{|l|l|l|l|l|l|}
\hline Modalku & $\begin{array}{l}\text { Yes } \\
\text { (Facebook, } \\
\text { Twitter, and } \\
\text { Linkedin) }\end{array}$ & $\begin{array}{l}\text { There is no } \\
\text { campaign }\end{array}$ & $\begin{array}{l}\text { UMKM } \\
\text { Funding and } \\
\text { early-stage } \\
\text { business }\end{array}$ & $\begin{array}{l}\text { Yes } \\
\text { (incentives are } \\
\text { given in the } \\
\text { form of interest } \\
\text { amounting to 12- } \\
28 \%)\end{array}$ & $\begin{array}{l}\text { Yes } \\
\text { (CNN } \\
\text { Indonesia, } \\
\text { Koran Sindo, } \\
\text { Kompas, and } \\
\text { others })\end{array}$ \\
\hline Indves & $\begin{array}{l}\text { Yes } \\
\text { (Facebook } \\
\text { and Twitter) }\end{array}$ & $\begin{array}{l}\text { Yes } \\
\text { (unspicified } \\
\text { moment) }\end{array}$ & $\begin{array}{l}\text { UMKM } \\
\text { Funding } \\
\text { andearly- } \\
\text { stage business }\end{array}$ & $\begin{array}{l}\text { Yes } \\
\text { (incentives are } \\
\text { given in the form } \\
\text { of profit sharing } \\
\text { from the project } \\
\text { owner) }\end{array}$ & No \\
\hline
\end{tabular}

Source: data processed, 2016

The table above is a description of crowdfunding work patterns seen from five aspects, namely Social Networking (SCN), Campaign Event (Event), User Motivation, Incentive Versioning and Critical Mass (Mass Media). Each crowdfunding portal has a difference operational works. OnSCN, all crowdfunding portals use social networks to campaign for their projects. The use of mass media would be a fairly good strategy, considering that Indonesia has now come into an era of disruption, where large-scale migrations into virtual life have occurred through social media networks. Indonesian people will spend more time visiting social networks than reading offline-newspapers. Therefore, the use of SCN is the right step to promote crowdfunding platforms to the public.

The second aspect observed in crowdfunding portals is the Campaign Event. Analyzing from a project campaign, each portal has different characteristics. Due topeer to peer debt-based crowdfunding, a project campaign has been a requirement in the contect of GandengTangan to attract prospective investors. The campaign period of GandengTangan has extenteda year in maximum campaign; after getting funds, it will automatically be GandengTangan member. Modalku, on the opposite, does 
not have a campaign period. The project owner can immediately apply for funding, the team will supervisethe feasibility project immediately. As it is considered as well-funded, the project owner will get such funds as the proposed budget andearnthe capital from members who have invested. Due to the absence of a campaign, the platform managers have many tasks, especially in the feasibility proposal.

The reason why some usersjoiningthe crowdfunding portals would be the next analysis. The three platforms have users who have the same goal as getting financial support. The member mostly come from startup business owners, while some have already developed their businesses yet need financial support to expand their business. The next aspect to be examined is incentive versioning, providing incentives for investors. Each platform has varying rewards. GandengTangan runs the reward which is delivered by the project owner to the investor directly without going through the platform. The projects that have been officially funded is a must to make a contribution to GandengTangan without any specific nominal value.

The Modalku distributes rewards to investors in the form of interest between 12-18\% depending on the amount of invested funds. For the project owners, it is an obligation to pay interest at 14-20\%. In doing so, a project platform of Modalku gets a profit of $2 \%$ of the nominal project. The Indves platform uses rewards in the form of profit sharing with mudharaba agreements. Indves applies a profit sharing system that does not burden the project owners, while the project gains a loss the owner does not have any obligation to pay its compensation. This system requires platform owners to monitor continuously funded businesses and ensure that the funded projects remain profitable.

The last aspect to be observed is the use of mass media. GandengTangan and Modalku platforms use such print media as newspapers 
to promote their platforms. Indves does not have mass media of business partners to promote its platform. The use of mass media in promoting platforms has been considered to be less effective for platforms that do not have sufficient funds to promote. The promotion through mass media will add the heavy operational burden.

\section{Potential Sharia Crowdfunding}

The existence of a sharia crowdfunding platform in Indonesia indicates that the Islamic finance business has developed into a new form (Abdullah \& Oseni, 2017; Kim \& De Moor, 2017; Thaker \& Pitchay, 2018). If the Islamic finance business has been dominated by financial institutions, both banks and non-banking system, the new sharia financial business has developed in the form of financial technology ( $\mathrm{Ng}$, Ibrahim, \& Mirakhor, 2015; Pitluck, 2016). The existence of crowdfunding platforms using sharia principles provide new wave of the Islamic finance. For start-up business owners, the existence of capital-based crowdfunding make it easier to obtain funding, with a fast and easy process and is not hindered by geographical area constraints. The niche market for sharia crowdfunding is still wide open. Moreover, this article finding shows that the development of crowdfunding platforms need to be improved; of the nine platforms, only one has positioned as sharia crowdfunding.

The uniqueness of sharia crowdfunding also presents a new challenge for the platform providers to have a sharia supervisory board. Sharia crowdfunding in turn would not be consideredas formality an sich, but graspingon sharia substance also. Majelis Ulama Indonesia (MUI) who has a duty to oversee sharia business in Indonesia shoud have wider responsibilities to develop financial technology in sharia context. The development of Islamic crowdfunding in Indonesia has advantages and disadvantages. This platform will expand the market share of the Islamic 
finance business, considering that sharia business has now penetrated into the world of crowdfunding business. In addition, the development of the digital world has had a lot of impact on people's lives, giving rise to a new order (Irfan, 2016), as well as that of Muslim life. As a manifestation of good technological use, speed and advanced technology can be used to support the success of the Islamic finance business in the digital era.

Along with the increasing digital technology, fraud are also haunted to disturb it. Protection for digital-based financial business is badly needed forthe crowdfunding users. Until 2016, the government has not provided legal certainty regarding crowdfunding official business and regulations in Indonesia. So far, crowdfunding consumers only conduct transactions based on trust without legal protection. This weakness should be a salient issue for the government to pay special attention to digitalbased businesses such as crowdfunding. Ths security side come to bea failure of crowdfunding business in Indonesia, due to the consumers are not protected In the near future, the government needs to take steps to provide legal certainty in the digital-based businesses.

Digital development has made it much easier for some to get funding from many parties (fundrising) (Adiansah, Mulyana, \& Fedryansah, 2016). The growth of a digital-based financial business can be a pillar of economic growth in Indonesia. It can support the development of business start-ups in Indonesia. This is in line with the sustainable development goals set out by the United Nations, along with 17 objectives and 169 measurable achievements, in a certain period of time. Crowdfunding practices are in line with the eighth goal, namely to realize decent work and economic growth, promote sustainable and inclusive economic growth, employment and decent work for all. Such crowdfunding platforms overcame obstacles for start up due to collateral constraints and business criteria. 


\section{Conclusion}

There are at least three crowdfunding platforms that supports MSMEs funding in Indonesia, i.e. Modalku, GandengTangan, and Indves. Modalku and GandengTangan are loan-based crowdfunding platforms, while Indves is an equity-based crowdfunding. Indves has been the first crowdfunding in Indonesia using sharia principles of its business management. As a sharia-based crowdfunding platform, Indves has proved that sharia business has ability to develop into a digital business. The challenge for platform managers and Majelis Ulama Indonesia is to supervise sharia financial principles working appropriately with technological business in Indonesia. The shifting business of digital disruption has not been responded to well by the government, causing anxiety about the survival of digital-based businesses because of the absence of protection for the consumers. The government needs to issue regulations related to digital-based financial businesses supporting economic growth and reaching financial inclusion.

\section{Acknowledgement}

The author was grateful for the support of funding granted from DIPA (Daftar Isian Pelaksanaan Anggaran) of Ministry of Religious Affairs (MORA) batch 2016. 


\section{References}

Abdullah, S., \& Oseni, U. A. (2017). Towards a sharīah compliant equitybased crowdfunding for the halal industry in Malaysia. International Journal of Business and Society, 18(S1), 223-240.

Adiansah, W., Mulyana, N., \& Fedryansah, M. (2016). Potensi crowdfunding di Indonesia dalam praktik pekerjaan sosial. In Prosiding Penelitian \& Pengabdian Kepada Masyarakat (Vol. 3, pp. 230-236). Retrieved from https://doi.org/10.24198/jppm.v3i2.13655.

Agrawal, A. ., Catalini, C., \& Goldfarb, A. (2011). The geography of crowdfunding.

Alexakis, C., \& Pappas, V. (2018). Sectoral dynamics of financial contagion in Europe - The cases of the recent crises episodes. Economic Modelling, 73, 222-239. https://doi.org/10.1016/j.econmod.2018.03.018.

Alqahtani, F., \& Mayes, D. G. (2018). Financial stability of Islamic banking and the global financial crisis: Evidence from the Gulf Cooperation Council. Economic Systems, 42(2), 346-360. https://doi. org/10.1016/j.ecosys.2017.09.001.

Benna, U. G., \& Benna, A. U. (2018). Crowdfunding and sustainable urban development in emerging economies. https://doi.org/10.4018/978-15225-3952-0.

Blowfield, M. (2012). Business and development: Making sense of business as a development agent. Corporate Governance (Bingley), 12(4), 414426. https://doi.org/10.1108/14720701211267775.

Boldea, M., \& Sirghi, N. (2011). Institutions and growth: Where do innovation and the people component of a process stand? (Vol. 3, pp. 1721-1728). Presented at the Innovation and Knowledge Management: A Global Competitive Advantage - Proceedings of the 16th International Business Information Management Association Conference, IBIMA 2011. 
Budisantoso, T., \& Nuritomo. (2016). Bank dan Lembaga Keuangan Lain. Jakarta: Salemba Empat.

Chaney, D. (2018). A principal-agent perspective on consumer co-production: Crowdfunding and the redefinition of consumer power. Article in Press. https://doi.org/10.1016/j.techfore.2018.06.013.

Chepurenko, A. (2015). Entrepreneurship Theory: New challenges and future prospects. Foresight Russia, 9(2), 44-57. https://doi. org/10.17323/1995-459X.2015.2.44.57.

Chirisa, I., \& Mukarwi, L. (2018). A comparative analysis of Africa and Chinese crowdfunding markets. In Crowdfunding and Sustainable Urban Development in Emerging Economies (pp. 147-163). https:// doi.org/10.4018/978-1-5225-3952-0.ch008.

Danmayr, F. (2014). Archetypes of Crowdfunding Platforms. Springer Gabler. Steyr: Springer Fachmedien Wiesbaden. Retrieved from https://doi.org/10.1017/CBO9781107410.1007/978-3-658-04559315324.004.

Departemen Koperasi. (2015). Data UMKM di Indonesia. Retrieved from http://www.depkop.go.id/berita-informasi/data-informasi/data-

Freedman, D. ., \& Nutting, M. . (2014). A brief history of crowdfunding. Retrieved from https://doi.org/10.1016/j.cell.2015.03.044.

Gerber, E. ., Hui, J. ., \& Kuo, P. . (2012). Crowdfunding: Why people are motivated to post and fund projects on crowdfunding platforms. Proc. of the International Workshop on ..., 10. Retrieved from https://doi. org/http://dx.doi.org/10.1145/2530540.

Gray, M., \& Zhang, B. (2017). Crowdfunding: Understanding diversity. In Handbook on the Geographies of Money and Finance (pp. 580-609). https://doi.org/10.4337/9781784719005.

Harris, M. D., Edmunds, P. K., \& Chen, J. (2011). Concerns and expectations of African American entrepreneurship students. Journal of Entrepreneurship Education, 14, 39-48. 
Hemer, J. (2011). A snapshot on crowdfunding. Retrieved from https:// doi.org/10.1227/01.NEU.0000349921.14519.2A.

Irfan, M. (2016). Crowdfunding sebagai pemaknaan energi gotong royong terbarukan. Share: Social Work Jurnal, 6(1), 30-42.

Kanani, M., \& Goodarzi, M. (2016). Fostering new technology-based firms in Iran: Inspiration of world models in solving domestic challenges. In The Development of Science and Technology in Iran: Policies and Learning Frameworks (pp. 29-43). https://doi.org/10.1057/978-1137-57257-8_3.

Kim, H., \& De Moor, L. (2017). The Case of Crowdfunding in Financial Inclusion: A Survey. Strategic Change, 26(2), 193-212. https://doi. org/10.1002/jsc.2120.

Lawton, K., \& Marom, D. (2010). The Crowdfunding Revolution; Social Networking Meets Venture Financing. USA: Amazon Digital Service.

Messeni Petruzzelli, A., Natalicchio, A., Panniello, U., \& Roma, P. (2018). Understanding the crowdfunding phenomenon and its implications for sustainability. Article in Press. https://doi.org/10.1016/j. techfore.2018.10.002.

Mohd Thas Thaker, M. A. B., \& Allah Pitchay, A. (2018). Developing waqf land through crowdfunding-waqf model (CWM): the case of Malaysia. Journal of Islamic Accounting and Business Research, 9(3), 448-456. https://doi.org/10.1108/JIABR-05-2016-0062.

Mohd Thas Thaker, M. A., Mohd Thas Thaker, H., \& Allah Pitchay, A. (2018). Modeling crowdfunders' behavioral intention to adopt the crowdfunding-waqf model (CWM) in Malaysia: The theory of the technology acceptance model. International Journal of Islamic and Middle Eastern Finance and Management, 11(2), 231-249. https:// doi.org/10.1108/IMEFM-06-2017-0157.

Mollick, E. (2014). The Dynamics of Crowdfunding: An Exploratory Study. Journal of Business Venturing, 29(1), 1-16. 
242 Indah Piliyanti

Vol. 3 No. 2, May - August 2018 


\section{Shirkah Author Guidelines}

Shirkah currently offers two routes to submit manuscripts. We highly recommend to submit the articles which are made using OJS (Open Journal System). Feel free register as author soon through visiting http:// shirkah.or.id/index.php/home/user/register. The authors may directly send their manuscripts, along with their resume, to shirkahiainsurakarta@ gmail.com. Please prepare your manuscripts, using following guidelines:

1. Manuscript must be written in English. Submitted articles should not have been published or be under review for publication with another journal.

2. Manuscript's length is about $15-20$ pages, typed in one-half spaced on A4-paper size.

3. Manuscript must include an $150-200$ word abstract and keywords.

4. Manuscript must be arranged as follows: Title, Name of Author, E-mail address, Abstract, Keywords, Introduction (including method if any), Discussion, Conclusion, References.

5. Manuscript's titles not more than ten words.

6. Manuscript must be submitted in Microsoft Word or RTF.

7. Arabic words should be transliterated according to the style of International Journal of Middle Eastern Studies.

8. Manuscript references are preferably derived from the up-to-date references.

9. The author's resume should be submitted separately, consisting of at least full name, institutional address, phone number, areas of studies, and recent publications (if any).

10. Shirkab use APA Style 6th edition (2010) as reference format writing. We suggest the use of a reference manager software such as Mendeley, Zotero, and Endnote at templating the citation style. APA Style to be used is as follows: 


\section{Book with single author}

Swann, G. M. Peter. (2014). The Economics of Innovation an Introduction. Cheltenhum \& Northampton: Edward Elgar.

in-text citation: (Swann, 2014)

\section{Articles in reference books}

Alatas, S. F. (2006). Islam and the Science of Economics in Abu Rabi', I.M. The Blackwell Companion to Contemporary Islamic Thought. USA: Willey-Blackwell (pp. 587-606).

in text citation: (Alatas, 2006)

\section{E-Book}

Hackett, Rosalind (2007). "Religous Dimentions of War and Peace: Introduction.” Dalam Gerrie ter Haar dan Yoshio Tsuruoka (Ed.), Religion and Society: An Agenda for the 21st Century (h. 3-6). Retrieved from http:// brill.nl.

in text citation: (Hackett, 2006)

\section{Master's thesis, from a commercial database}

McNieI, D. S. (2006). Meaning through narrative: A personal narrative discussing growing up with an alcoholic mother (Master's thesis). Available from ProQuest Dissertations and Theses database. (UMI No. 1434728)

in text citation: (Mc Niel, 2006)

\section{Doctoral dissertation, from an institutional database}

Adams, R. J. (1973). Building a foundation for evaluation of instruction in higher education and continuing education (Doctoral dissertation). Retrieved from http://www.ohiolink.edu/etd/

in text citation: (Adams, 1973) 


\section{Doctoral dissertation, from the web}

Bruckman, A. (1997). MOOSE Crossing: Construction, community, and learning in a networked virtual world for kids (Doctoral dissertation, Massachusetts Institute of Technology). Retrieved from http:/www-static. cc.gatech.edu/--asb/thesis/

in text citation: (Bruckman, 1997)

\section{Journal article with No DOI}

Bourkhis, K., and Nabi, M. S. (2013). Islamic and conventional banks' soundness during the 2007-2008 financial crisis. Journal Metrics, 22(2), 68-77.

in-text citation: (Bourkhis \& Nabi, 2013).

\section{Journal article with DOI}

Ichwan, M. (2012). The Local Politics Of Orthodoxy: The Majelis Ulama Indonesia in the Post-New Order Banten. Journal Of Indonesian Islam, 6(1), 166-194. doi:http://dx.doi.org/10.15642/JIIS.2012.6.1.166-194

In text citation : (Ichwan, 2012)

\section{Abstract as citation}

Hasan, N. (2012). Islamist Party, Electoral Politics And Da'wah Mobilization Among Youth : The Prosperous Justice Party (PKS) in Indonesia. Journal of Indonesian Islam, 6(1), 17-47. Abstract from http:// jiis.uinsby.ac.id/index.php/jiis/article/view/97

in text citation : (Hasan, 2012)

\section{Mass media article}

Sahal, Akhmad (2014, March 2). Kiai Sahal dan Realisme Fikih.Tempo Magazine, p. 120.

in text citation : (Sahal, 2014) 


\section{Research report}

Fisher, B. S., Cullen, F. T., \& Turner, M. G. (2000). The Sexual Victimization of College Women. Research Report.

in text citation : (Fisher, Cullen, Turner, 2000)

\section{Monograph}

Routray, Bibhu Prasad (2013), National Security Decision-Making in India (RSIS Monograph No. 27). Singapura: Rajaratnam School of International Studies.

in text citation : (Routray, 2013)

\section{Proceeding article}

Sudibyakto, Hizbaron, D.R., \& Jati, R (Ed.) (2009), Proceeding International Seminar Disaster Theory, Research and Policy. International seminar held by Sekolah Pascasarjana, Universitas Gajahmada, Yogyakarta, 8-9 Desember 2009.

in text citation : (sudibyakto and Jati, 2009)

\section{Paper conference/seminar/symposium}

Janutama, Herman Sinung (2011). "Kraton dan Hubungan Antar Agama." Paper presented in Seminar Kraton dan Panatagama held by Center for the Study of Islam and Social Transformation (CISForm), Yogyakarta, 17 November.

in text citation :(Janutama, 2011)

\section{Online article in web}

Shiva, (2006, February). Bioethics: A Third World Issue. Native-web. Diperoleh dari http://www.nativeweb.org/ pages/legal/shiva.html

in text citation : (Shiva, 2006) 


\section{Online research report}

Kessy, S. S. A., \& Urio, F M. (2006). The contribution of microfinance institutions to poverty reduction in Tanzania (Research Report No. 06.3). Retrieved from Research on Poverty Alleviation website: http://www. repoa.or.tz /documents_storage/Publications/Reports/06.3_Kessy_and_ Urio.pcif

in text citation : (kessy and urion, 2006)

\section{Holy book}

Qur an, $2(25)$

In text citation : (Q. al-Baqarah 2:25).

\section{Encyclopaedia}

Graycar, Adam (1992). Social Welfare Policy. Dalam Mary Hawkesworth dan Maurice Kogan (Ed.), Encyclopedia of Government and Politics (Vol. 1). London: Routledge.

in text citation : (Graycar, 1992)

\section{Interview}

Sultan Hamengkubuwono X (interview, 2011, April 19)

in text citation: (Hamengkubuwono, 2011)

\section{Documentary film}

Steijlen, Fridus (2008). A Day in the Life of Indonesia [documentary film, 58 minutes]. Leiden: KITLV Press.

in text citation : (Steijlen, 2008) 
Vol. 3 No. 2, May - August 2018 